\title{
The impact of initial antibiotic treatment failure: real-world insights in patients with complicated, health care-associated intra-abdominal infection
}

This article was published in the following Dove Medical Press journal: Infection and Drug Resistance

\author{
Pascale Peeters' \\ Kellie Ryan ${ }^{2}$ \\ Sudeep Karve ${ }^{2}$ \\ Danielle Potter ${ }^{3}$ \\ Elisa Baelen ${ }^{4}$ \\ Sonia Rojas-Farreras ${ }^{5}$ \\ Jesús Rodríguez-Baño ${ }^{6}$ \\ 'Real-World Insights, IQVIA, Saint- \\ Ouen, France; ${ }^{2}$ Health Economics and \\ Outcomes Research, AstraZeneca, \\ Gaithersburg, MD, USA; ${ }^{3}$ Medical \\ Evidence and Observational Research \\ Center, AstraZeneca, Gaithersburg, \\ MD, USA; ${ }^{4}$ Real-World Insights, IQVIA, \\ St Prex, Switzerland; ${ }^{5}$ Real-World \\ Insights, IQVIA, Barcelona, Spain; \\ ${ }^{6}$ Department of Medicine, Unidad \\ Clínica de Enfermedades Infecciosas, \\ Microbiología y Medicina Preventiva, \\ Hospital Universitario Virgen \\ Macarena - Instituto de Biomedicina \\ de Sevilla (IBiS), Universidad de \\ Sevilla, Seville, Spain
}

Purpose: The RECOMMEND study (NCT02364284; D4280R00005) assessed the clinical management patterns and treatment outcomes associated with initial antibiotic therapy (IAT; antibiotics administered $\leq 48$ hours post-initiation of antibiotic therapy) for health care-associated infections across five countries.

Patients and methods: Data were collected from a retrospective chart review of patients aged $\geq 18$ years with health care-associated complicated intra-abdominal infection (cIAI). Potential risk factors for IAT failure were identified using logistic regression analyses.

Results: Of 385 patients with complete IAT data, bacterial pathogens were identified in 270 (70.1\%), including Gram-negative isolates in 221 (81.9\%) and Gram-positive isolates in 92 (34.1\%). Multidrug-resistant (MDR) pathogens were identified in 112 patients ( $41.5 \%$ of patients with a pathogen identified). IAT failure rate was $68.3 \%$ and in-hospital mortality rate was $40.8 \%$. Multivariate regression analysis demonstrated three factors to be significantly associated with IAT failure: patients admitted/transferred to the intensive care unit during index hospitalization, isolation of an MDR pathogen and previous treatment with $\beta$-lactam antibiotics.

Conclusion: We reveal the real-world insights into the high rates of IAT failure and mortality observed among patients with cIAI. These data highlight the challenges associated with choosing IAT, the impact of MDR pathogens on IAT outcomes and the importance of tailoring IAT selection to account for local epidemiology and patient history.

Keywords: complicated intra-abdominal infection, health care associated, initial antibiotic treatment, clinical outcome, real-world treatment patterns

\section{Introduction}

Complicated intra-abdominal infections (cIAIs) occur when the infectious process of an intra-abdominal infection (IAI) extends beyond the limits of one organ, causing localized or diffuse infection of the peritoneum that is usually polymicrobial in nature. ${ }^{1}$ The bacterial flora that comprise the infection are generally dependent on the specific location of the site of the perforation of the gastrointestinal tract in community-acquired cIAI. $^{2}$ Health care-associated cIAIs frequently result from previous intra-abdominal surgery, and therefore, the nature of the infecting nosocomial pathogen is typically defined by a combination of the site of the operation and the hospital. ${ }^{2}$ cIAIs that occur in a health care-associated setting (hospital-acquired or acquired in another health care setting) are generally associated with higher mortality rates than communityacquired IAIs. This increased mortality is due, in part, to the likely poorer underlying health status of patients in health care facilities and the impact of comorbidities on prognosis. ${ }^{3}$ In addition, patients acquiring cIAI after surgery may have nutritional
Correspondence: Jesús Rodríguez-Baño Departamento de Medicina, Unidad Clínica de Enfermedades Infecciosas, Microbiología y Medicina Preventiva, Hospital Universitario Virgen Macarena Instituto de Biomedicina de Sevilla (IBiS), Avda Dr Fedriani 3, 41009 Seville, Spain $\mathrm{Tel}+34671592434$

Fax +34955926552

Email jesusrb@us.es 
deficiency, altered intestinal flora and immune deficiency that also impact on prognosis. ${ }^{4}$ There is also the potential for the involvement of a broader spectrum of microorganisms in health care-associated infection, ${ }^{5}$ with an increased likelihood that the causative pathogens are multidrug resistant (MDR). ${ }^{6}$ Pathogens typically isolated from health care-associated cIAIs are Gram-negative organisms, most commonly Escherichia coli, Klebsiella pneumoniae and Pseudomonas aeruginosa; Gram-positive species, namely, Enterococcus spp.; and anaerobic species. ${ }^{7}$ The increasing global prevalence of MDR pathogens in this setting, in particular, the continuing spread of extended-spectrum $\beta$-lactamase-producing Gram-negative Enterobacteriaceae, is a major concern for the treatment of cIAIs. ${ }^{8-10}$

Management of cIAI requires both timely surgical source control and empirical initial antibiotic therapy (IAT), followed by a switch to a more specific antibiotic regimen based on bacterial culture results. ${ }^{6,11,12}$ To provide adequate coverage, IAT typically incorporates broad-spectrum antibiotics, sometimes in combination. ${ }^{12}$ However, resistance rates in cIAI isolates are constantly changing and are also subject to regional variation; thus, local epidemiology must be accounted for to ensure that this empirical approach covers the relevant pathogens and does not contribute further to the development of antibiotic resistance. ${ }^{9,10,13-15}$

In severe health care-associated infections, delayed IAT and the administration of inappropriate antibiotics have both been linked with IAT failure, increased morbidity and mortality and an increased burden on health care resources. ${ }^{16-19}$ There is a need, therefore, to gain a better understanding of the treatment patterns and risk factors associated with IAT failure, and the impact of IAT failure on patients in a realworld setting. To date, very few studies have looked, on an international scale, at the outcome of IAT in patients with health care-associated cIAI. Clinical trial eligibility criteria often restrict the inclusion of patients with comorbid diseases, so their findings may not be representative of real-world patients. $^{20,21}$ Furthermore, published observational studies have addressed mixed patient populations predominantly with community-acquired infections, rather than health careassociated infections. ${ }^{5,22}$

The RECOMMEND study (NCT02364284, D4280R00005) involved a comprehensive review of the medical records of patients with health care-associated cIAI, complicated urinary tract infection (cUTI) and nosocomial pneumonia (NP) across five different countries. The aim of the study was to evaluate the treatment patterns and clinical outcomes among these patients, including an assessment of the IAT outcomes and risk factors associated with IAT failure. Analyses relating to patients with cIAI are reported here.

\section{Patients and methods}

\section{Study design}

RECOMMEND was an international, retrospective, multicenter, non-interventional cohort study based on a retrospective chart review of hospitalized adult patients with health care-associated cIAI, cUTI or NP from Brazil, France, Italy, Russia and Spain, between July 1, 2013 and June 30, 2014. The study was designed and performed in accordance with the ethical principles of the Declaration of Helsinki. The study was consistent with the sponsor's policy on bioethics, the harmonized tripartite guideline E6(R1) from the International Conference on Harmonization, Good Clinical Practice and applicable regulatory requirements. The study protocol was reviewed and approved by an ethics committee (EC) or an institutional review board (IRB) at each site, except in France, where this is not required for retrospective studies, and Spain, where the national regional regulatory agency evaluated and classified the study in addition to EC approvals. The names of the ECs and IRBs providing their approval for the conduct of this study can be found in Table S1. Site investigators were responsible for obtaining informed consent from the patient or their legal representative in accordance with the local regulations.

Data were collected in an electronic case report form based on patient medical records covering the patient from diagnosis to 30 days' post-discharge, death, loss to follow-up or the end of the study period (December 31, 2014) if not discharged by the end of the study.

\section{Patients}

For inclusion in the current analysis, patients had to be aged $\geq 18$ years and have a clinical diagnosis of health careassociated cIAI requiring surgical intervention as previously defined, ${ }^{21}$ with evidence of involvement of more than one organ causing peritonitis, and parenteral antibiotic therapy during the hospital stay beyond the 24-hour regimen associated with surgery. Health care-associated infection was defined as hospital acquired (developed $\geq 48$ hours after hospital admission) or acquired in another health care setting, including hospitals, nursing homes, long-term care facilities or hemodialysis clinics, $\leq 3$ months prior to or during in-patient admission. Patients were excluded from the study if they had taken part in any clinical trial during the patient selection or follow-up period. 
Patients were identified using the ICD-10th revision codes or diagnosis-related group codes from the hospital discharge records, the health care-associated infection registry or other site-specific sources. Inclusion and exclusion criteria were applied to the corresponding medical charts and the final selection of eligible patients was at the discretion of the investigator, applying the criteria used in routine practice to identify patients with complicated infections. Each site could accrue a maximum of 40 patients per type of infection.

\section{Study measures}

The primary objective of the study was to document the association of clinical outcomes with IAT (defined as all antibiotic agents administered during the 48 hours post-initiation of antibiotic therapy) and determine the factors associated with IAT success and failure. Success was defined as discontinuation of IAT, including de-escalation or streamlining, because of clinical cure or improvement, with no further need for an antibiotic; or a switch to oral antibiotic; and no readmission due to the same infection within 30 days of discharge. Failure was defined as discontinuation of the antibiotic regimen for reasons other than cure, de-escalation or streamlining; a change in IAT due to perceived clinical failure; a dose increase or addition of another antibiotic beyond 48 hours of treatment; the requirement of an additional source control procedure performed $>48$ hours post-IAT; in-hospital death of any cause; or readmission due to recurrence of the same infection within 30 days of discharge. In cases in which there was insufficient information to conclude whether the IAT outcome was a failure or a success, an indeterminate outcome was concluded. Data were collected for IAT and up to four additional lines of antibiotic treatment following IAT. A new line of antibiotic treatment was defined as any change occurring after 48 hours of initiation of antibiotic therapy, including discontinuation, an increase in dose, a switch to oral therapy or the addition of a new antibiotic.

Additional information captured from medical records comprised baseline details relating to patients, pathogens and sites, including patient age, sex, comorbidity burden, pathogen type and the presence of MDR pathogens. To be classified as MDR, pathogens had to display resistance to at least one antibiotic in a minimum of three of any of the following drug classes: aminoglycosides, chloramphenicol, carbapenems, cephalosporins, glycylcycline, penicillins \pm $\beta$-lactamase inhibitors, quinolones, tetracyclines, macrolides or streptogramins for all pathogens; or glycopeptides, oxazolidinones and lipopeptides for Gram-positive pathogens; or mono-bactams for Gram-negative pathogens; or nitroimidazole for anaerobic pathogens. The incidence of IAT failure, in-hospital mortality rate, mortality rate at 30 days' post-discharge, incidence of hospital readmissions within 30 days' post-discharge, incidence of secondary infections, hospital length of stay, and total number of days on IAT and four additional lines of antibiotic treatment were also noted. Details of treatment were recorded, including antibiotic type(s), monotherapy or a combination of antibiotics, and the physician-reported reason for ending treatment.

\section{Statistical analyses}

All variables were reported using descriptive statistics, and data were analyzed overall and by country. The association of IAT failure with potential risk factors (characteristics of patients [demographic and clinical], pathogens, sites and treatment) was explored using univariate and multivariate logistic regression analyses. For the regression analyses, indeterminate outcomes were grouped with treatment successes. The multivariate regression analysis included variables from the univariate analysis with $P<0.25$ as the potential confounders. ORs, corresponding 95\% CIs and $P$-values were calculated. All analyses were performed by Quintiles using SAS ${ }^{\circledR}$ (SAS Institute Inc., Cary, NC, USA) version 9.4 .

\section{Results \\ Patient demographic and clinical characteristics}

Data from 26 hospital sites across the five participating countries were collected (Brazil, $n=4$; France, $n=6$; Italy, $\mathrm{n}=6$; Russia, $\mathrm{n}=4$; Spain, $\mathrm{n}=6$ ). Across all three indications of interest, 1,708 potential patients were identified, and 1,321 patients were enrolled based on the inclusion criteria for each indication and patient consent, where applicable (not required in Spain). Complete start and stop records for IAT were available for 1,244 patients (cIAI, $\mathrm{n}=385$; cUTI, $\mathrm{n}=408$; NP, $\mathrm{n}=451$ ).

In total, $385(30.9 \%)$ out of 1,244 patients were included with health care-associated cIAI as their index infection, with a mean (SD) age at hospital admission of 64.4 (15.7) years and a relatively even split of male to female patients $(56.4 \%$ male overall), as shown in Table 1.

The majority (62.1\%) were enrolled with hospitalacquired cIAI. The most common cIAI conditions $(\geq 10 \%$ of patients) were secondary peritonitis $(37.4 \%)$, intra-abdominal abscess (30.4\%) and cholecystitis (16.4\%). The mean (SD) Deyo-Charlson comorbidity score (DCCS) was 2.4 (2.5), 
Table I Patient demographic and clinical characteristics at index hospitalization, overall and by country

\begin{tabular}{|c|c|c|c|c|c|c|}
\hline Parameters & $\begin{array}{l}\text { Brazil } \\
(n=89)\end{array}$ & $\begin{array}{l}\text { France } \\
(n=65)\end{array}$ & $\begin{array}{l}\text { Italy } \\
(n=68)\end{array}$ & $\begin{array}{l}\text { Russia } \\
(n=74)\end{array}$ & $\begin{array}{l}\text { Spain } \\
(n=89)\end{array}$ & $\begin{array}{l}\text { Total } \\
(\mathbf{N}=385)\end{array}$ \\
\hline \multicolumn{7}{|l|}{ Age, years } \\
\hline Mean (SD) & $57.9(17.4)$ & $67.3(12.4)$ & $67.5(14.3)$ & $62.7(15.6)$ & $67.7(15.3)$ & $64.4(15.7)$ \\
\hline \multicolumn{7}{|l|}{ Sex } \\
\hline Male, n (\%) & $43(48.3)$ & $40(61.5)$ & $41(60.3)$ & $36(48.6)$ & $57(64.0)$ & $217(56.4)$ \\
\hline \multicolumn{7}{|l|}{ Weight, kg } \\
\hline $\mathrm{n}$ (non-missing) & 76 & 63 & $4 I$ & 52 & 34 & 266 \\
\hline Mean (SD) & $71.9(21.1)$ & $70.6(15.7)$ & $73.9(12.0)$ & $84.0(19.1)$ & $73.3(13.4)$ & $74.5(17.9)$ \\
\hline $\begin{array}{l}\text { Patients with comorbidity requiring } \\
\text { hospitalization or treatment (surgery/ } \\
\text { chronic or current drug therapy), n (\%) }\end{array}$ & $72(80.9)$ & $52(80.0)$ & $61(89.7)$ & $60(81.1)$ & $82(92.1)$ & $327(84.9)$ \\
\hline DCCS, mean (SD) & $1.7(1.9)$ & $2.5(2.7)$ & $3.7(3.1)$ & $1.9(2.0)$ & $2.4(2.4)$ & $2.4(2.5)$ \\
\hline \multicolumn{7}{|l|}{ DCCS, n (\%) } \\
\hline 0 & $36(40.4)$ & $23(35.4)$ & II (16.2) & $20(27.0)$ & $23(25.8)$ & $113(29.4)$ \\
\hline $\mathrm{I}-2$ & $30(33.7)$ & $13(20.0)$ & $18(26.5)$ & $35(47.3)$ & $31(34.8)$ & $127(33.0)$ \\
\hline $3-4$ & $15(16.9)$ & $17(26.2)$ & $14(20.6)$ & $10(13.5)$ & $19(21.3)$ & $75(19.5)$ \\
\hline$\geq 5$ & $8(9.0)$ & $12(18.5)$ & $25(36.8)$ & $9(12.2)$ & $16(18.0)$ & $70(18.2)$ \\
\hline \multicolumn{7}{|l|}{ Number of comorbidities by patient } \\
\hline $\mathrm{n}$ (non-missing) & 72 & 52 & 61 & 60 & 82 & 327 \\
\hline Number, mean (SD) & $2.0(1.0)$ & $2.8(1.6)$ & $3.2(2.1)$ & $2.1(1.2)$ & $2.5(1.6)$ & $2.5(1.6)$ \\
\hline \multicolumn{7}{|l|}{$\begin{array}{l}\text { Comorbidity ( } \geq 10 \% \text { of overall patients), } \\
\text { n (\%) }\end{array}$} \\
\hline $\mathrm{N}$ & 72 & 52 & 61 & 60 & 82 & 327 \\
\hline Hypertension & $34(47.2)$ & $30(57.7)$ & $28(45.9)$ & $38(63.3)$ & $43(52.4)$ & $173(52.9)$ \\
\hline Malignancy & $22(30.6)$ & $13(25.0)$ & $29(47.5)$ & $11(18.3)$ & $26(31.7)$ & $101(30.9)$ \\
\hline Diabetes & $20(27.8)$ & $13(25.0)$ & $15(24.6)$ & $\mathrm{II}(18.3)$ & $25(30.5)$ & $84(25.7)$ \\
\hline COPD & $2(2.8)$ & $\mathrm{II}(2 \mathrm{I} .2)$ & $7(11.5)$ & $8(13.3)$ & $9(11.0)$ & $37(11.3)$ \\
\hline Renal insufficiency & $8(1 \mathrm{I} . \mathrm{I})$ & $5(9.6)$ & $14(23.0)$ & $0(0.0)$ & $9(11.0)$ & $36(11.0)$ \\
\hline Liver disease & $3(4.2)$ & $5(9.6)$ & $10(16.4)$ & $8(13.3)$ & $9(11.0)$ & $35(10.7)$ \\
\hline \multicolumn{7}{|l|}{$\begin{array}{l}\text { Hospitalized within } 90 \text { days prior to the } \\
\text { index hospitalization, } \mathrm{n}(\%)\end{array}$} \\
\hline Yes & $28(31.5)$ & $17(26.2)$ & $32(47.1)$ & $15(20.3)$ & $30(33.7)$ & $122(3 \mid .7)$ \\
\hline No & $52(58.4)$ & $33(50.8)$ & $30(44.1)$ & $54(73.0)$ & $56(62.9)$ & $225(58.4)$ \\
\hline Unknown & $9(10.1)$ & $15(23.1)$ & $6(8.8)$ & $5(6.8)$ & $3(3.4)$ & $38(9.9)$ \\
\hline \multicolumn{7}{|l|}{$\begin{array}{l}\text { Patient administered any antibiotics } \\
\text { within } 90 \text { days prior to the index } \\
\text { diagnosis, } \mathrm{n}(\%)\end{array}$} \\
\hline Yes & $29(32.6)$ & $19(29.2)$ & $21(30.9)$ & $\mathrm{I}(\mathrm{I} .4)$ & $48(53.9)$ & $118(30.6)$ \\
\hline No & $43(48.3)$ & $21(32.3)$ & $32(47.1)$ & $50(67.6)$ & $33(37.1)$ & $179(46.5)$ \\
\hline Unknown & $17(19.1)$ & $25(38.5)$ & $15(22.1)$ & $23(3 \mathrm{I} . \mathrm{I})$ & $8(9.0)$ & $88(22.9)$ \\
\hline \multicolumn{7}{|l|}{ If yes, antibiotic class, n (\%) } \\
\hline$\beta$-lactam antibacterials, penicillins & $5(17.2)$ & $9(47.4)$ & $5(23.8)$ & $0(0.0)$ & $23(47.9)$ & $42(35.6)$ \\
\hline Other $\beta$-lactam antibacterials & $12(4 \mid .4)$ & $8(42.1)$ & $5(23.8)$ & $I(100)$ & $13(27.1)$ & $39(33.1)$ \\
\hline Quinolone antibacterials & $10(34.5)$ & $\mathrm{I}(5.3)$ & $5(23.8)$ & $0(0.0)$ & $4(8.3)$ & $20(16.9)$ \\
\hline Other antibacterials & $0(0.0)$ & $0(0.0)$ & $3(14.3)$ & $0(0.0)$ & $5(10.4)$ & $8(6.8)$ \\
\hline Aminoglycoside antibacterials & $0(0.0)$ & $\mathrm{I}(5.3)$ & $0(0.0)$ & $0(0.0)$ & $2(4.2)$ & $3(2.5)$ \\
\hline Sulfonamides and trimethoprim & $2(6.9)$ & $0(0.0)$ & $\mathrm{I}(4.8)$ & $0(0.0)$ & $\mathrm{I}(2.1)$ & $4(3.4)$ \\
\hline All other therapeutic products & $0(0.0)$ & $0(0.0)$ & $2(9.5)$ & $0(0.0)$ & $0(0.0)$ & $2(1.7)$ \\
\hline \multicolumn{7}{|l|}{ Acquisition of clAl, n (\%) } \\
\hline Hospital-acquired & $48(53.9)$ & $42(64.6)$ & $38(55.9)$ & $55(74.3)$ & $56(62.9)$ & $239(62.1)$ \\
\hline Health care-associated & $4 I(46 . I)$ & $23(35.4)$ & $30(44.1)$ & $19(25.7)$ & $33(37.1)$ & $146(37.9)$ \\
\hline
\end{tabular}

Note: Percentages are calculated with numbers of patients for whom data were available as the denominator for each category as the denominator for each category. Abbreviations: clAl, complicated intra-abdominal infection; DCCS, Deyo-Charlson comorbidity score. 
with 327 (84.9\%) of 385 patients having at least one comorbidity that required hospitalization, chronic or ongoing drug therapy, or surgical treatment (Table 1).

Within the 90 days prior to index hospitalization, 122 (31.7\%) patients had been hospitalized at least once and 118 (30.6\%) had received antibiotics. Of those who had received prior antibiotics, the majority had received either $\beta$-lactam-based penicillin or another $\beta$-lactam-based antibacterial (Table 1).

The majority of patients in this cIAI cohort underwent a surgical intervention $(295 / 385,76.6 \%)$, with the majority of those surgeries being for the purpose of source control of the infection $(218 / 295,73.9 \%)$. A second surgical intervention to control the source infection was required by $20.2 \%$ of those who underwent surgery, and $13.3 \%$ required three or more surgical interventions. Of note, the proportion of patients who underwent surgery and required three or more surgical interventions to control the source infection was numerically higher in Brazil and Russia $(22.0 \%$ and $19.7 \%$, respectively) than in other countries $(\leq 10.0 \%)$, as shown in Table 2.

\section{Pathogen characteristics}

At least one bacterial pathogen was identified in 270 (70.1\%) patients. Among the 454 bacterial pathogens isolated, 46 were isolated before the start of IAT, 309 were isolated within $0-6$ days of the start of IAT and 133 were isolated 7 days or more after the start of IAT. Of the 270 patients, $221(81.9 \%)$ had a Gram-negative pathogen isolated, 92 (34.1\%) had a Grampositive pathogen and $21(7.8 \%)$ had an anaerobic pathogen (a patient could have more than one pathogen type identified; Figure 1 and Table S2). The most commonly isolated Gram-negative pathogens ( $\geq 10 \%$ of patients) were $E$. coli (47.0\%), Klebsiella spp. (17.0\%) and P. aeruginosa (11.1\%); however, differences were noted across countries (Figure 1 and Table S2). The most commonly isolated Gram-positive pathogens overall were Enterococcus spp. (20.0\% of patients in the overall cIAI cohort), although again, differences were noted across countries.

MDR pathogens were isolated in $41.5 \%$ of all patients who had a pathogen identified, with the highest incidence observed in Russia and the lowest in Brazil and Italy (Figure 1 and Table S2). Among individual species, MDR isolates were identified in $32(25.2 \%)$ out of 127 patients for E. coli, 25 (54.3\%) out of 46 patients for Klebsiella spp., $9(30.0 \%)$ out of 30 patients for P. aeruginosa, $27(50.0 \%)$ out of 54 patients for Enterococcus spp., 12 (41.4\%) out of 29 patients for Staphylococcus spp. and 13 (92.9\%) out of 14 patients for Acinetobacter spp. In patients in whom any MDR pathogen was isolated, resistance was most common to penicillins either with or without $\beta$-lactamase inhibitors (63.4\% and $73.2 \%$, respectively), quinolones

Table 2 Summary of procedures performed during hospitalization for the index infection

\begin{tabular}{|c|c|c|c|c|c|c|}
\hline Parameters & $\begin{array}{l}\text { Brazil } \\
(n=89)\end{array}$ & $\begin{array}{l}\text { France } \\
(n=65)\end{array}$ & $\begin{array}{l}\text { Italy } \\
(n=68)\end{array}$ & $\begin{array}{l}\text { Russia } \\
(n=74)\end{array}$ & $\begin{array}{l}\text { Spain } \\
(n=89)\end{array}$ & $\begin{array}{l}\text { Total } \\
(N=385)\end{array}$ \\
\hline \multicolumn{7}{|c|}{$\begin{array}{l}\text { Patients with procedures undertaken during } \\
\text { hospitalization for the index infection, } n(\%)\end{array}$} \\
\hline Surgical intervention ${ }^{\mathrm{a}}$ & $77(86.5)$ & $4 I(63.1)$ & $47(69.1)$ & $68(91.9)$ & $62(69.7)$ & $295(76.6)$ \\
\hline $\mathrm{I}^{\mathrm{b}}$ & $45(58.4)$ & $25(61.0)$ & $33(70.2)$ & $37(54.4)$ & $32(5 \mathrm{I} .6)$ & $175(58.3)$ \\
\hline $2^{\mathrm{b}}$ & $15(19.5)$ & $6(14.6)$ & $10(21.3)$ & $18(26.5)$ & $20(32.3)$ & $69(23.4)$ \\
\hline$\geq 3^{b}$ & $17(22.1)$ & $10(24.4)$ & $4(8.5)$ & $13(19.1)$ & $10(16.1)$ & $54(18.3)$ \\
\hline Mechanical ventilation & $54(60.7)$ & $28(43.1)$ & $12(17.6)$ & $28(37.8)$ & $24(27.0)$ & $146(37.9)$ \\
\hline Other procedure & $19(21.3)$ & $4(6.2)$ & $17(25.0)$ & $0(0.0)$ & $37(4 I .6)$ & $77(20.0)$ \\
\hline Endoscopy & $6(6.7)$ & $7(10.8)$ & $7(10.3)$ & $6(8.1)$ & II (I2.4) & $37(9.6)$ \\
\hline None & $0(0.0)$ & $20(30.8)$ & $8(11.8)$ & $2(2.7)$ & $5(5.6)$ & $35(9.1)$ \\
\hline Tracheostomy & $10(11.2)$ & $0(0.0)$ & $\mathrm{I}(\mathrm{I} .5)$ & $17(23.0)$ & $6(6.7)$ & $34(8.8)$ \\
\hline Hemodialysis & II (12.4) & $9(13.8)$ & $3(4.4)$ & $3(4.1)$ & $4(4.5)$ & $30(7.8)$ \\
\hline \multicolumn{7}{|c|}{$\begin{array}{l}\text { Number of surgical interventions to control the } \\
\text { source infection }\end{array}$} \\
\hline $\mathrm{n}$ & 50 & 30 & 24 & 61 & 53 & 218 \\
\hline $\mathrm{I}$ & $31(62.0)$ & $20(66.7)$ & $20(83.3)$ & $7(60.7)$ & $37(69.8)$ & $145(66.5)$ \\
\hline 2 & $8(16.0)$ & $7(23.3)$ & $3(12.5)$ & $12(19.7)$ & $14(26.4)$ & $44(20.2)$ \\
\hline$\geq 3$ & II (22.0) & $3(10.0)$ & I (4.2) & $12(19.7)$ & $2(3.8)$ & $29(13.3)$ \\
\hline
\end{tabular}

Notes: Percentages are calculated with numbers of patients for whom data were available as the denominator for each category as the denominator; total of percentages may exceed $100 \%$. More than one procedure may apply for a single patient. aSurgical interventions refer to open abdomen procedures. Percutaneous interventions, interventional radiology and laparoscopic procedures were recorded as "other procedures", including those performed to control the infection. ${ }^{b}$ (\%) of those undergoing a surgical intervention. 
A

Brazil $(n=64)$

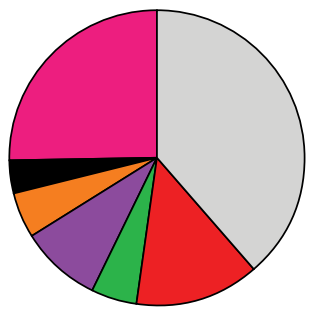

C

Italy $(n=44)$

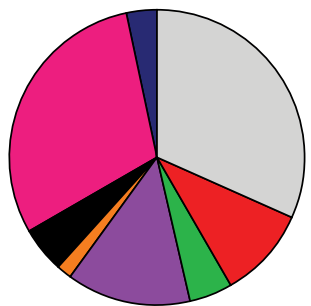

E

Spain $(n=71)$

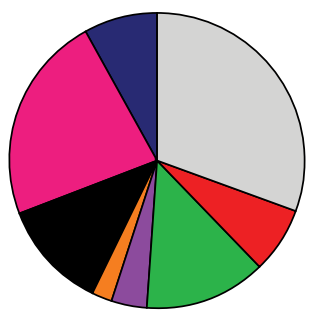

48.4\% Escherichia coli

- $17.2 \%$ Klebsiella spp.

6.3\% Pseudomonas aeruginosa

- $10.9 \%$ Enterobacter spp.

- $6.3 \%$ Acinetobacter spp.

- $4.7 \%$ Other gram-negative bacteria

- $31.3 \%$ Gram-positive bacteria

- $0.0 \%$ Anaerobic bacteria

Figure I Most common bacterial pathogens identified in specimen samples from patients in Brazil (A), France (B), Italy (C), Russia (D), Spain (E) and overall (F). Notes: Patients could have more than one pathogen type identified. Data missing for 22 patients in Brazil. Percentages are calculated as a proportion of those patients with $\geq$ I bacterial pathogen identified.

(69.6\%), aminoglycosides (64.3\%), cephalosporins $(62.5 \%)$, macrolides $(33.0 \%)$, carbapenems $(31.3 \%)$ and tetracyclines $(21.4 \%)$.

\section{IAT treatment patterns}

In the cIAI cohort, $48.6 \%$ of patients (187/385) received a single antibiotic as their IAT, while the remaining $51.4 \%$ (198/385) received a combination of antibiotics. The mean (SD) duration of IAT was 11.1 (20.2) days. Notably, IAT duration was shorter in patients receiving monotherapy than in those receiving combination therapy (Table 3). Large inter-country variation was observed in the antibiotics used throughout the study. The most common agents used either as a monotherapy or as part of a combination therapy are presented in Table 3 (all agents used as part of any IAT therapy in $\geq 5 \%$ of the total population). Across all countries, the most frequent monotherapy IATs $(\geq 5 \%$ of those receiving monotherapy) were $\beta$-lactams/ $\beta$-lactamase inhibitors
B

France $(\mathrm{n}=48)$

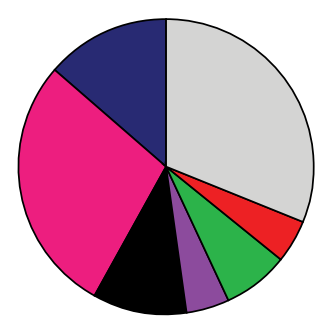

D

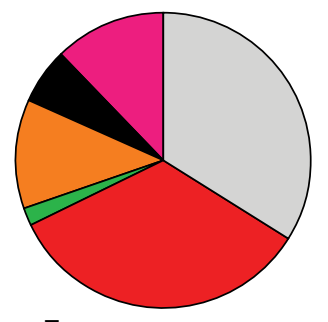

$\mathbf{F}$

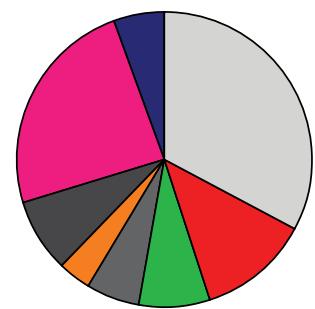

$43.8 \%$ Escherichia coli

- $6.3 \%$ Klebsiella spp.

- $10.4 \%$ Pseudomonas aeruginosa

- $6.3 \%$ Enterobacter spp.

$0.0 \%$ Acinetobacter spp.

- $14.6 \%$ Other Gram-negative bacteria

- $39.6 \%$ Gram-positive bacteria

- $18.8 \%$ Anaerobic bacteria

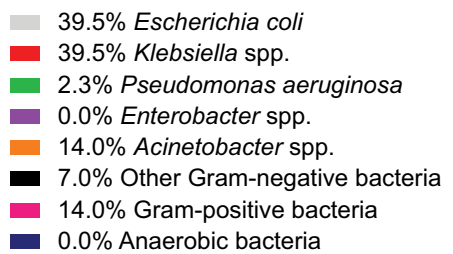

$47.0 \%$ Escherichia coli

- $17.0 \%$ Klebsiella spp.

- $11.1 \%$ Pseudomonas aeruginosa

- $8.5 \%$ Enterobacter spp.

- $5.2 \%$ Acinetobacter spp.

- $11.5 \%$ Other Gram-negative bacteria

- $34.1 \%$ Gram-positive bacteria

- $7.8 \%$ Anaerobic bacteria 
Table 3 Characteristics of IAT overall and by country

\begin{tabular}{|c|c|c|c|c|c|c|}
\hline Parameter & $\begin{array}{l}\text { Brazil } \\
(n=89)\end{array}$ & $\begin{array}{l}\text { France } \\
(n=65)\end{array}$ & $\begin{array}{l}\text { Italy } \\
(n=68)\end{array}$ & $\begin{array}{l}\text { Russia } \\
(n=74)\end{array}$ & $\begin{array}{l}\text { Spain } \\
(n=89)\end{array}$ & $\begin{array}{l}\text { Total } \\
(\mathbf{N}=385)\end{array}$ \\
\hline \multicolumn{7}{|l|}{ Type of therapy, $n(\%)$} \\
\hline Monotherapy & $48(53.9)$ & $25(38.5)$ & $34(50.0)$ & $26(35.1)$ & $54(60.7)$ & $187(48.6)$ \\
\hline Combination therapy & $4 I(46 . I)$ & $40(6 I .5)$ & $34(50.0)$ & $48(64.9)$ & $35(39.3)$ & $198(51.4)$ \\
\hline \multicolumn{7}{|l|}{ IAT duration, days, mean (SD) } \\
\hline All IAT & $8.6(8.1)$ & $14.0(45.9)$ & $\mathrm{II} .0(7.8)$ & $10.8(7.4)$ & II.8 (9.I) & II.I (20.2) \\
\hline Monotherapy & $8.5(8.9)$ & $5.7(3.8)$ & $10.7(7.4)$ & $6.9(4.1)$ & $11.6(9.0)$ & $9.2(7.9)$ \\
\hline Combination therapy & $8.6(7.0)$ & $19.2(58.1)$ & $\mathrm{II} .3(8.2)$ & $13.0(8.0)$ & $12.0(9.3)$ & $12.8(27.1)$ \\
\hline \multicolumn{7}{|c|}{$\begin{array}{l}\text { Most common IAT given as a monotherapy or as a part of } \\
\text { a combination therapy ( } \geq 5 \% \text { of the total population), } n(\%)\end{array}$} \\
\hline Piperacillin-tazobactam & II (12.4) & $32(49.2)$ & $25(36.8)$ & $0(0.0)$ & $42(47.2)$ & $110(28.6)$ \\
\hline Metronidazole & $23(25.8)$ & $15(23.1)$ & $19(27.9)$ & $41(55.4)$ & $12(13.5)$ & $110(28.6)$ \\
\hline Ceftriaxone & $6(6.7)$ & II (I6.9) & $4(5.9)$ & $38(5 \mathrm{I} .4)$ & $2(2.2)$ & $61(15.8)$ \\
\hline Ciprofloxacin & $23(25.8)$ & $5(7.7)$ & $7(10.3)$ & $2(2.7)$ & $9(10.1)$ & $46(11.9)$ \\
\hline Amikacin & $0(0.0)$ & $15(23.1)$ & $0(0.0)$ & $16(21.6)$ & $6(6.7)$ & $37(9.6)$ \\
\hline Meropenem & $9(10.1)$ & $\mathrm{I}(\mathrm{I} .5)$ & II (I6.2) & $\mathrm{I}(\mathrm{I} .4)$ & $12(13.5)$ & $34(8.8)$ \\
\hline Ampicillin + sulbactam & $22(24.7)$ & $0(0.0)$ & $8(11.8)$ & $3(4.1)$ & $0(0.0)$ & $33(8.6)$ \\
\hline Vancomycin & $10(11.2)$ & $7(10.8)$ & $5(7.4)$ & $0(0.0)$ & $8(9.0)$ & $30(7.8)$ \\
\hline Cefotaxime & $0(0.0)$ & $0(0.0)$ & $3(4.4)$ & $14(18.9)$ & $5(5.6)$ & $22(5.7)$ \\
\hline Imipenem & $\mathrm{I}(\mathrm{I} . \mathrm{I})$ & $8(12.3)$ & $5(7.4)$ & $0(0.0)$ & $6(6.7)$ & $20(5.2)$ \\
\hline \multicolumn{7}{|l|}{ Reason for IAT discontinuation, $\mathrm{n}(\%)^{\mathrm{a}}$} \\
\hline Cure & $20(22.7)$ & $29(44.6)$ & $27(40.3)$ & $24(32.4)$ & $26(29.2)$ & $126(32.9)$ \\
\hline Perceived clinical failure & $49(55.7)$ & $9(13.8)$ & $15(22.4)$ & $17(23.0)$ & $19(21.3)$ & $109(28.5)$ \\
\hline De-escalation & $4(4.5)$ & $17(26.2)$ & $14(20.9)$ & $5(6.8)$ & $32(36.0)$ & $72(18.8)$ \\
\hline Death & $14(15.9)$ & $11(16.9)$ & $8(11.9)$ & $19(25.7)$ & $5(5.6)$ & $57(14.9)$ \\
\hline Isolation of a resistant pathogen & $4(4.5)$ & $3(4.6)$ & II (I6.4) & $2(2.7)$ & $15(16.9)$ & $35(9.1)$ \\
\hline Secondary infection requiring regimen change & $6(6.8)$ & $3(4.6)$ & $3(4.5)$ & $12(16.2)$ & $4(4.5)$ & $28(7.3)$ \\
\hline Switch to oral therapy & $0(0.0)$ & $2(3.1)$ & $4(6.0)$ & $0(0.0)$ & $5(5.6)$ & II (2.9) \\
\hline Adverse event & $0(0.0)$ & $\mathrm{I}(\mathrm{I} .5)$ & $2(3.0)$ & $0(0.0)$ & $3(3.4)$ & $6(1.6)$ \\
\hline
\end{tabular}

Note: aPatient might report more than one reason for stopping IAT.

Abbreviation: IAT, initial antibiotic treatment.

$75.9 \%(101 / 133), 84.0 \%(63 / 75)$ and $48.6 \%(18 / 37)$ of the patients in the second to fifth treatment lines, respectively. Overall, the mean (SD) total number of days of antibiotic therapy, including all lines of treatment, was 26.3 (53.8) days (Table 4). This was shorter in cases of IAT success than IAT failure or indeterminate outcome. However, variation in overall treatment duration was observed across the different countries (Table 4).

\section{Clinical outcomes of IAT}

IAT failure was identified in $263(68.3 \%)$ patients in the overall cIAI cohort, with similar rates across all countries (Table 4). Patients receiving monotherapy had numerically higher rates of IAT failure compared to those receiving combination therapy (70.6\% vs $66.2 \%$, respectively; Figure 2 ). IAT success and indeterminate outcomes were observed in $22.5 \%$ and $7.0 \%$, respectively, of patients receiving monotherapy and in $28.8 \%$ and $5.1 \%$, respectively, of patients receiving combination therapy.

For all patients, the overall mean (SD) length of hospital stay from admission to discharge was 28.8 (30.8) days. Length of hospital stay did not differ greatly by IAT treatment outcome, except in Brazil, where patients with IAT success had a numerically shorter length of hospital stay than those with IAT failure (Table 4). The overall in-hospital mortality rate was $40.8 \%$, although this varied across the participating countries, being highest in Brazil and lowest in Spain and Italy. The 30-day post-discharge mortality rate was $41.0 \%$ (Table 4).

There was a numerically higher rate of IAT failure in patients with MDR pathogens identified (81.3\%) than those without $(62.7 \%)$ in the overall cohort; this was observed consistently across all participating countries except France, where the IAT failure rates in patients with or without an 
Table 4 Treatment outcome measures, overall and by country

\begin{tabular}{|c|c|c|c|c|c|c|}
\hline Parameter & $\begin{array}{l}\text { Brazil } \\
(n=89)\end{array}$ & $\begin{array}{l}\text { France } \\
(n=65)\end{array}$ & $\begin{array}{l}\text { Italy } \\
(n=68)\end{array}$ & $\begin{array}{l}\text { Russia } \\
(n=74)\end{array}$ & $\begin{array}{l}\text { Spain } \\
(n=89)\end{array}$ & $\begin{array}{l}\text { Total } \\
(\mathrm{N}=385)\end{array}$ \\
\hline \multicolumn{7}{|l|}{ IAT outcome, n (\%) } \\
\hline Failure $^{\mathrm{a}}$ & $70(78.7)$ & $42(64.6)$ & $42(61.8)$ & $53(71.6)$ & $56(62.9)$ & $263(68.3)$ \\
\hline Success & $18(20.2)$ & $20(30.8)$ & $22(32.4)$ & $19(25.7)$ & $20(22.5)$ & $99(25.7)$ \\
\hline Indeterminate & $\mathrm{I}(\mathrm{I} . \mathrm{I})$ & $3(4.6)$ & $4(5.9)$ & $2(2.7)$ & $13(14.6)$ & $23(6.0)$ \\
\hline $\begin{array}{l}\text { Treatment duration (all lines of } \\
\text { therapy), mean (SD) days }\end{array}$ & $18.0(15.3)$ & $19.7(46.0)$ & $24.3(47.9)$ & $26.2(6 \mid .6)$ & $4 I .0(75.0)$ & $26.3(53.8)$ \\
\hline \multicolumn{7}{|l|}{$\begin{array}{l}\text { Duration by IAT outcome, mean } \\
\text { (SD) days }\end{array}$} \\
\hline Failure & $20.5(16.3)$ & $14.4(12.2)$ & $20.1(12.0)$ & $32.2(72.0)$ & $52.6(92.1)$ & $28.7(55.8)$ \\
\hline Success & $8.2(3.4)$ & $32.2(81.0)$ & $31.6(83.1)$ & $\mathrm{II} .5(5.7)$ & I6.I (I4.4) & $20.5(53.9)$ \\
\hline Indeterminate & 15.0 (NA) & $9.7(5.5)$ & $27.8(14.9)$ & $7.5(0.7)$ & $29.3(14.6)$ & $24.0(15.0)$ \\
\hline $\begin{array}{l}\text { LOS (from admission to discharge), } \\
\text { mean (SD) days }\end{array}$ & $22.2(17.3)$ & $28.5(23.8)$ & $34.3(48.4)$ & $19.6(14.5)$ & $39.2(34.9)$ & $28.8(30.8)$ \\
\hline \multicolumn{7}{|l|}{$\begin{array}{l}\text { LOS by IAT outcome, mean (SD) } \\
\text { days }\end{array}$} \\
\hline Failure & $25.5(17.8)$ & $29.6(27.8)$ & $25.2(14.9)$ & $21.6(16.1)$ & $43.9(39.2)$ & $29.3(26.0)$ \\
\hline Success & $9.1(6.3)$ & $28.7(13.9)$ & $51.5(80.4)$ & $15.2(7.2)$ & $27.9(26.7)$ & $27.5(42.4)$ \\
\hline Indeterminate & $22.0(\mathrm{NA})$ & $13.0(9.5)$ & $34.3(25.4)$ & $8.0(1.4)$ & $36.2(20.3)$ & $29.7(20.8)$ \\
\hline In-hospital mortality rate, $\mathrm{n}(\%)$ & $50(56.2)$ & $30(46.2)$ & $18(26.5)$ & $40(54.1)$ & $19(21.3)$ & $157(40.8)$ \\
\hline With MDR pathogen, n/N (\%) & $15 / 20(75.0)$ & $8 / 23(34.8)$ & $5 / 14(35.7)$ & $16 / 22(72.7)$ & $6 / 33(18.2)$ & $50 / 112(44.6)$ \\
\hline Without MDR pathogen, $\mathrm{n} / \mathrm{N}(\%)$ & $20 / 44(45.5)$ & $12 / 25(48.0)$ & $7 / 30(23.3)$ & $9 / 21(42.9)$ & 9/38 (23.7) & $57 / 158(36.1)$ \\
\hline 30-day mortality rate, $\mathrm{n}(\%)$ & $50(56.2)$ & $30(46.2)$ & $18(26.5)$ & $40(54 . I)$ & $20(22.5)$ & $158(41.0)$ \\
\hline With MDR pathogen, n/N (\%) & $15 / 20(75.0)$ & $8 / 23(34.8)$ & $5 / 14(35.7)$ & $16 / 22(72.7)$ & $7 / 33(21.1)$ & $5 \mathrm{I} / \mathrm{I} / 2(45.5)$ \\
\hline Without MDR pathogen, n/N (\%) & $20 / 44(45.5)$ & $12 / 25(48.0)$ & $7 / 30(23.3)$ & $9 / 21(42.9)$ & $9 / 38(23.7)$ & $57 / 158(36.1)$ \\
\hline $\begin{array}{l}\text { Number of days from initiation of } \\
\text { IAT to patient's death (within } 30 \\
\text { days of discharge), mean (SD) }\end{array}$ & $19.6(17.2)$ & $18.7(20.7)$ & $15.8(13.0)$ & $18.4(15.5)$ & $41.6(47.9)$ & $21.5(24.2)$ \\
\hline
\end{tabular}

Notes: ${ }^{a}$ IAT failure defined as discontinuation of the antibiotic regimen for reasons other than cure/improvement in symptoms, including dose increase or addition of another antibiotic beyond 48 hours of treatment, in-hospital death of any cause or readmission due to recurrence of the same infection within 30 days of discharge. Streamlining, de-escalation or switch to oral antibiotics was not considered as treatment failure.

Abbreviations: IAT, initial antibiotic treatment; LOS, length of hospital stay; MDR, multidrug resistant, NA, not applicable.

MDR pathogen identified were roughly similar (Figure 3). In the overall cohort of patients with an MDR pathogen identified, the in-hospital and 30-day post-discharge mortality rates were also slightly higher than in those with no MDR pathogen identified. However, this was not consistently reflected across countries (Table 4).

\section{Univariate and multivariate factors associated with IAT failure}

Factors associated with IAT failure identified by the univariate (unadjusted) analysis $(P \leq 0.25)$ for consideration in the multivariate analysis were age: country; intensive care unit (ICU) admission; DCCS; site-level resistance to thirdgeneration cephalosporins, third-generation carbapenems, or combined site-level resistance to both; patient-level presence of MDR pathogens; prior hospitalization within 90 days prior to the index hospitalization and treatment with $\beta$-lactams within 90 days prior to the index hospitaliza- tion (Table 5). Accounting for these confounding factors, a multivariate model was developed. The final model had a Hosmer-Lemeshow $\chi^{2}$ value of 1.3467 with five degrees of freedom $(P=0.9301)$, indicating no evidence of lack of fit. The final model also had deviance and Pearson $\chi^{2}$ values of 138.01 and 128.03 with 116 degrees of freedom $(P=0.0799$ and $P=0.2097$ ), respectively, indicating no evidence to reject the fitted model. Using this model, three predictive factors with a statistically significant association with IAT failure $(P \leq 0.05)$ were identified: patients admitted or transferred to an ICU setting during their index hospitalization $(P=0.024)$, patient-level isolation of an MDR pathogen $(P<0.001)$ and treatment with $\beta$-lactam antibiotics within 3 months prior to the index diagnosis $(P=0.025)$.

\section{Discussion}

IAT treatment patterns, outcomes and potential risk factors for IAT failure in patients with health care-associated 

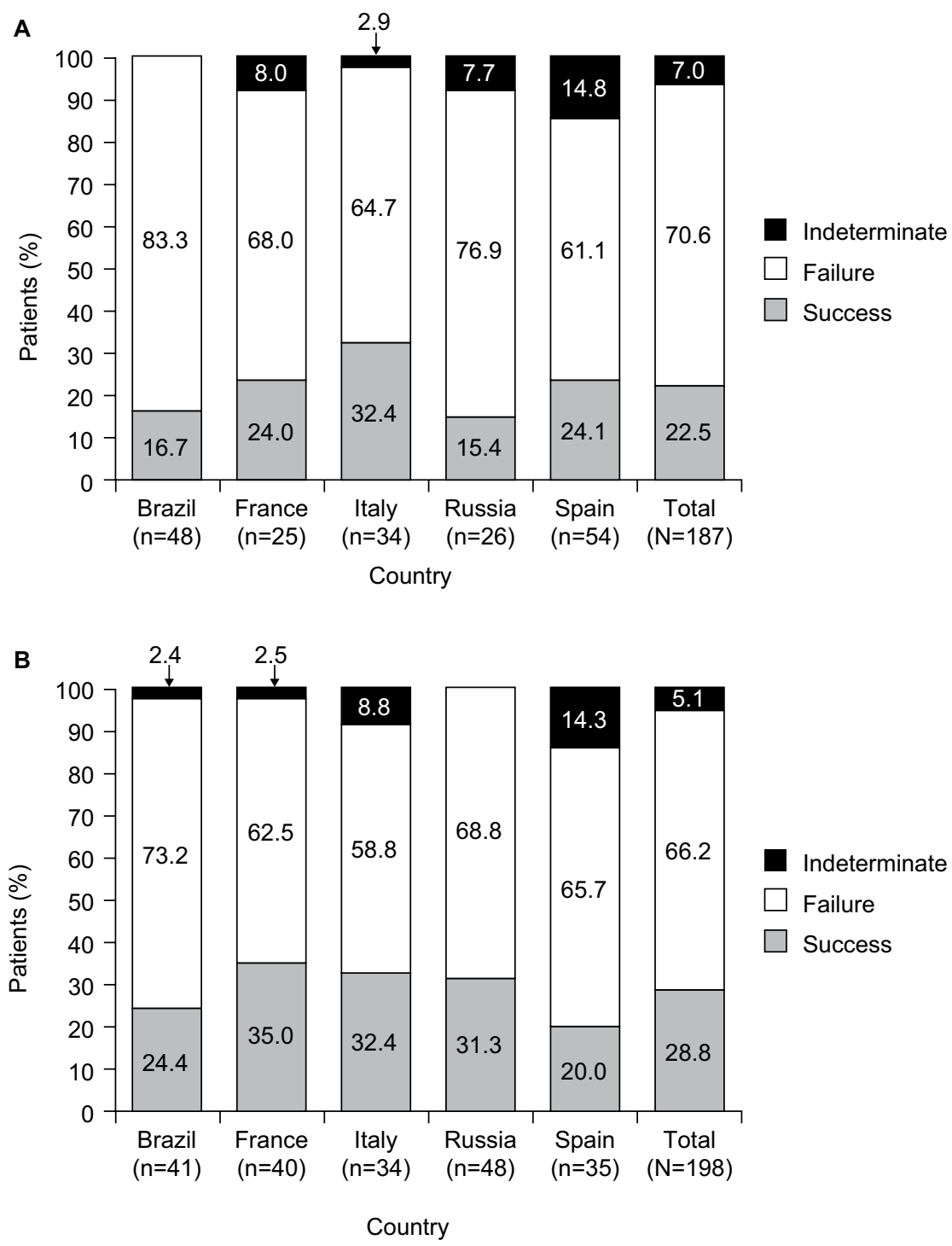

Figure 2 Clinical outcomes of initial antibiotic therapy in patients receiving (A) monotherapy or (B) combination therapy.

infections, including cIAI, were assessed with a view to presenting a practicable insight into clinical management across Brazil, France, Italy, Spain and Russia. This is one of the first studies to look at the real-world outcomes and treatment patterns across these countries in patients with health care-associated cIAI.

Patient and disease characteristics and pathogen identification documented here were in line with the few other observational studies that have looked at clinical, microbiological and treatment profiles of community- and health care-acquired cIAIs. ${ }^{5,22}$ Importantly, the frequency of comorbidities and previous number of admissions were high in this cohort. The most commonly observed pathogens (E. coli, Klebsiella spp. and P. aeruginosa) were reflective of those that have previously been associated with cIAI in more stringently selected populations within clinical trials ${ }^{21,23}$ and those observed in surveillance studies. ${ }^{9}$ Of note, the proportion of patients from whom anaerobes were isolated was heterogeneous, which may reflect differences in sampling and microbiological procedures.

Across all countries in this study, IAT failure was observed in over two-thirds of patients. Failure rates were high $(>60 \%)$ in each individual country, with higher rates observed in Brazil and Russia. The percentage of patients with an indeterminate outcome was low across all countries and unlikely to have affected the results observed. The high rate of failure may be due, in part, to the patient population 
A

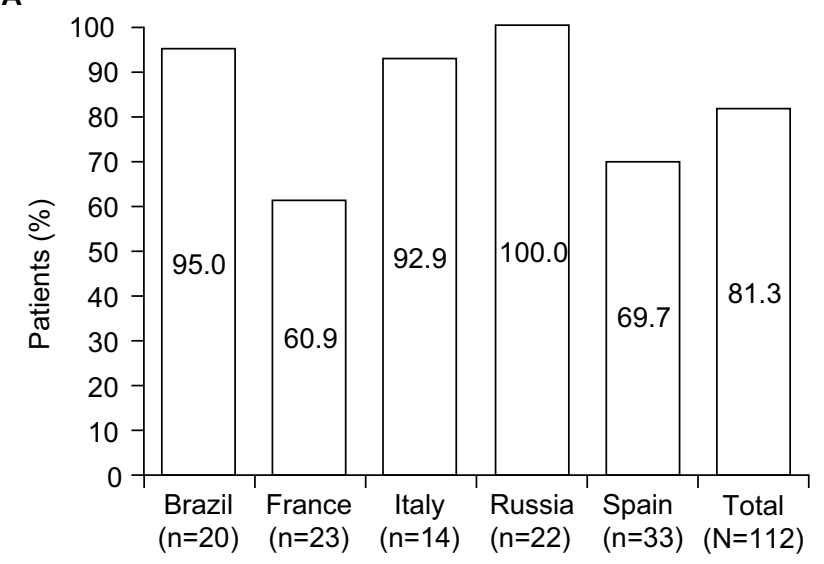

B

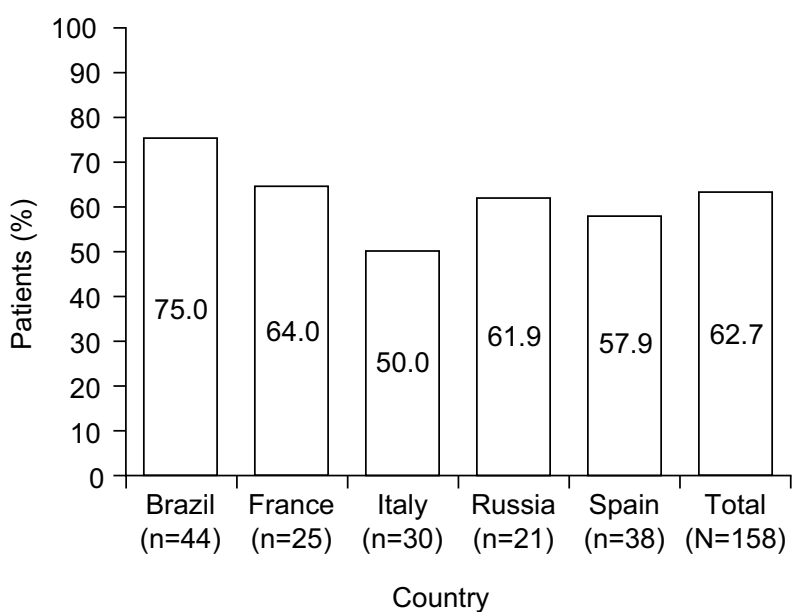

Figure 3 Initial antibiotic therapy failure in patients (A) with and (B) without multidrug-resistant pathogens identified.

included and the definition of IAT failure used. However, such criteria reflect real-world antibiotic use in this group of patients.

In critically ill patients, empiric IAT has an integral role in the success of treating health care-associated infections. ${ }^{16-19}$ Appropriate IAT choice is an important contributing factor to the likelihood of treatment success. ${ }^{1}$ Treatment guidelines advise that IAT for IAI should comprise a spectrum covering possible etiological pathogens, including Gram-negatives and anaerobes. ${ }^{12,24}$ This can be monotherapy active against both or combination therapies that provide the coverage required. IAT should also be tailored to account for known local intrinsic resistance mechanisms of likely etiological pathogens and, in the health care-associated setting, coverage for P. aeruginosa and Gram-positive bacteria such as Enterococcus spp. is recommended. ${ }^{1,25}$
In the present study, large inter-country variation was observed in the specific antibiotics used, potentially due to differences in the availability and cost of antibiotics across the different countries or the prescribing patterns accounting for local resistance patterns. However, from the relatively high level of IAT failure observed and the proportion of patients with perceived clinical failure requiring subsequent lines of antibiotic therapy, IAT selection in some of these patients might have been suboptimal, providing limited or compromised efficacy against the subsequently identified pathogens.

With an ever-increasing prevalence of MDR pathogens isolated from cIAIs, antimicrobial resistance among health care-associated pathogens has been identified as one of the major challenges in the management of cIAI..$^{7,922}$ In the present study, just under half of the patients with pathogens identified had an MDR pathogen isolated. This is consistent with the literature, which shows a higher proportion of MDR pathogens among health care-associated infections than community-acquired infections. ${ }^{6}$ The definition of MDR in this study was in line with that proposed in a European Center for Disease Prevention and Control and Centers for Disease Control and Prevention initiative. ${ }^{26}$ The multivariate analyses performed demonstrate that the presence of an MDR pathogen and treatment with $\beta$-lactam antibiotics within the 3 months prior to index infection are associated with an increased risk of IAT failure. It is noteworthy that it was specifically pretreatment with $\beta$-lactam antibiotics and not any other pretreatment that was significantly associated with IAT failure. While it is expected that the use of previous antibiotics would select patients with drug-resistant pathogens, the effect of previous $\beta$-lactam use was independent of isolation of an MDR pathogen. These data support the importance of understanding and interpreting treatment guidelines to account for patient history and the local epidemiology. ${ }^{14,16,27,28}$

In addition to high IAT failure rates, the overall mortality rates observed here were higher than the average mortality rates seen in other observational studies (typically around $10 \%$ or less), which mostly included less-complicated community-acquired infections. ${ }^{5,22,29,30}$ However, it is recognized that the cause of death has not been analyzed and may not be related to the index infection.

Limitations of this study pertained mostly to its retrospective design, which limited data availability to information in the patient record and, given the relative ease of enrolling deceased vs living patients, may have favored the selection of a more severely ill patient population. Severity of illness may be reflected in the relatively high proportion of patients who were admitted or transferred to the ICU and may explain the 
Table 5 Statistical predictors of initial antibiotic treatment failure - univariate and multivariate analyses

\begin{tabular}{|c|c|c|c|c|}
\hline \multirow[t]{2}{*}{ Potential risk factors } & \multicolumn{2}{|c|}{ Univariate analysis } & \multicolumn{2}{|c|}{ Multivariate analysis } \\
\hline & OR $(95 \% \mathrm{Cl})$ & $P$-value & OR $(95 \% \mathrm{Cl})$ & P-value \\
\hline \multicolumn{5}{|l|}{ Age, years } \\
\hline $18-44^{\mathrm{a}}$ & Reference & $0.050^{\mathrm{b}}$ & - & - \\
\hline $45-64$ & I.42 $(0.70,2.89)$ & & - & - \\
\hline$\geq 65$ & $2.14(1.07,4.26)$ & & - & - \\
\hline \multicolumn{5}{|l|}{ Gender } \\
\hline Female $^{\mathrm{a}}$ & Reference & 0.785 & & \\
\hline Male & $0.94(0.61,1.45)$ & & & \\
\hline \multicolumn{5}{|l|}{ Country } \\
\hline Spain $^{\mathrm{a}}$ & Reference & $0.093^{b}$ & - & - \\
\hline Brazil & $2.17(1.12,4.22)$ & & - & - \\
\hline France & $\mathrm{I} .08(0.55,2.09)$ & & - & - \\
\hline Italy & $0.95(0.50,1.83)$ & & - & - \\
\hline Russia & $1.49(0.77,2.89)$ & & - & - \\
\hline \multicolumn{5}{|c|}{ Number of days in hospital before the start of IAT } \\
\hline $0.7^{\mathrm{a}}$ & Reference & 0.393 & - & - \\
\hline $8-14$ & $0.67(0.35,1.28)$ & & - & - \\
\hline $15-30$ & $0.69(0.3 \mathrm{I}, \mathrm{I} .5 \mathrm{I})$ & & - & - \\
\hline$>30$ & $0.50(0.15,1.69)$ & & - & - \\
\hline \multicolumn{5}{|c|}{ ICU admission (initial admission or transfer) } \\
\hline $\mathrm{No}^{\mathrm{a}}$ & Reference & $<0.00 \mathrm{I}^{\mathrm{b}}$ & Reference & - \\
\hline Yes & $2.31(1.48,3.59)$ & & $2.49(\mathrm{I} .13,5.5 \mathrm{I})$ & 0.024 \\
\hline \multicolumn{5}{|l|}{ DCCS } \\
\hline $0^{\mathrm{a}}$ & Reference & $0.080^{\mathrm{b}}$ & - & - \\
\hline $\mathrm{I}-2$ & $1.16(0.68,1.96)$ & & - & - \\
\hline $3-4$ & $2.10(1.08,4.06)$ & & - & - \\
\hline$\geq 5$ & $1.77(0.92,3.42)$ & & - & - \\
\hline \multicolumn{5}{|c|}{$\begin{array}{l}\text { Site-level resistance to third-generation } \\
\text { cephalosporins }{ }^{c}\end{array}$} \\
\hline $\mathrm{No}^{\mathrm{a}}$ & Reference & $0.132^{\mathrm{b}}$ & - & - \\
\hline Yes & $0.99(0.98,1.00)$ & & - & - \\
\hline \multicolumn{5}{|c|}{$\begin{array}{l}\text { Site-level resistance to third-generation } \\
\text { carbapenems }^{c}\end{array}$} \\
\hline $\mathrm{No}^{\mathrm{a}}$ & Reference & $0.032^{\mathrm{b}}$ & - & - \\
\hline Yes & $0.99(0.98,1.00)$ & & - & - \\
\hline \multicolumn{5}{|c|}{$\begin{array}{l}\text { Combined site-level resistance to third- } \\
\text { generation cephalosporins and carbapenems }{ }^{c}\end{array}$} \\
\hline $\mathrm{No}^{\mathrm{a}}$ & Reference & $0.00 \mathrm{I}^{\mathrm{b}}$ & - & - \\
\hline Yes & $0.98(0.96,0.99)$ & & - & - \\
\hline \multicolumn{5}{|c|}{ Patient-level presence of MDR pathogen } \\
\hline $\mathrm{No}^{\mathrm{a}}$ & Reference & $<0.00 I^{\mathrm{b}}$ & Reference & - \\
\hline Yes & $2.58(1.46,4.58)$ & & $5.45(2.05, \mathrm{I} 4.52)$ & $<0.001$ \\
\hline \multicolumn{5}{|c|}{$\begin{array}{l}\text { Hospitalized within } 90 \text { days prior to the index } \\
\text { hospitalization }\end{array}$} \\
\hline $\mathrm{No}^{\mathrm{a}}$ & Reference & $0.019^{b}$ & - & - \\
\hline Yes & $1.78(I .09,2.91)$ & & - & - \\
\hline \multicolumn{5}{|c|}{$\begin{array}{l}\text { Treated with } \beta \text {-lactam antibiotic within the past } \\
3 \text { months }\end{array}$} \\
\hline $\mathrm{No}^{\mathrm{a}}$ & Reference & $0.008^{b}$ & Reference & - \\
\hline Yes & $2.03(1.18,3.52)$ & & $3.20(1.15,8.87)$ & 0.025 \\
\hline
\end{tabular}

Notes: In this analysis, treatment outcome is either failure or success/indeterminate. The logistic regression coding is: $I=$ failure, $0=$ success or indeterminate. ${ }^{\text {Reference }}$ category. 'Variables identified as significant in the univariate logistic regression analysis $(P \leq 0.25)$ were analyzed by multivariate logistic regression analysis. Data shown are from the final model using the stepwise backward selection process; therefore, only significant data that remained in the final model for the multivariate analysis are shown. 'On-site level of antibiotic resistance of Gram-negative isolates to third-generation cephalosporins, carbapenems or both combined.

Abbreviations: DCCS, Deyo-Charlson comorbidity score; IAT, initial antibiotic treatment; ICU, intensive care unit; MDR, multidrug resistant. 
association of this factor with IAT failure during multivariate analysis, although this should be interpreted with caution due to differences in hospital requirements and practice patterns for admission to the ICU. Given a lack of consensus on the definition for IAT failure, the study used a composite definition, which included additional interventions for infection source control and death due to any cause. With the relatively high level of comorbid conditions in these patients and their underlying medical conditions, inclusion of all-cause death may have overestimated the rate of IAT failure and led to worse outcomes than those observed in other published literature in this area.

Despite these limitations, the present study provides a global, real-world insight into current treatment patterns for patients with cIAI, the impact of IAT failure in patients who have been treated according to current cIAI practice and the potential risk factors associated with IAT failure. These data reiterate the challenges presented when choosing IAT, as well as the need for ongoing epidemiological studies and communication between microbiologists and prescribing physicians that will assist in providing a more tailored approach to IAT selection. This study was unique in looking specifically at the risk factors associated with IAT failure and in using IAT failure as an endpoint. With the paramount importance of effective early antibiotic treatment in cIAI, a broader awareness of local resistance epidemiology and further understanding of the influence of these risk factors on IAT and overall clinical outcome will help guide IAT selection and cIAI management.

\section{Data sharing}

Upon request, and subject to certain criteria, conditions and exceptions (see https://www.pfizer.com/science/clinicaltrials/trial-data-and-results for more information), Pfizer will provide access to individual de-identified participant data from Pfizer-sponsored global interventional clinical studies conducted for medicines, vaccines and medical devices: 1) for indications that have been approved in the USA and/or European Union; or 2) in programs that have been terminated (ie, development for all indications has been discontinued). Pfizer will also consider requests for the protocol, data dictionary and statistical analysis plan. Data may be requested from Pfizer trials 24 months after study completion. The de-identified participant data will be made available to researchers whose proposals meet the research criteria and other conditions, and for which an exception does not apply, via a secure portal. To gain access, data requestors must enter into a data access agreement with Pfizer.

\section{Acknowledgments}

The authors would like to thank the site investigators involved in the RECOMMEND study, including the following principal investigators: Alina Agafyina, Amine Si Ali, David Boutoille, Francesco Castelli, Domingos Otávio Lorenzoni d'Ávila, Antônio Tarcísio de Faria Freire, Anne-Laure Fedou, Juan Pablo Horcajada Gallego, Andrea Gori, Miquel Sabria Leal, Maria Patelli Juliani Souza Lima, Nadezhda Logvinenko, Jose Antonio Martinez Martinez, Isabel Morales, Giampietro Pellizzer, Nicola Petrosillo, Vera Petrova, Gaetan Plantefeve, Anne-Marie Rogues, Esther Calbo Sebastian, Yury Spesivtsev, Eduardo Sprinz, Philippe Vanhems, Fernando Vazquez Valdes, Mario Venditti and Pierluigi Viale. Medical writing support was provided by Catherine Savage, $\mathrm{PhD}$, and Valerie Moss, PhD, Certified Medical Publication Professional ${ }^{\mathrm{TM}}$, at Prime, Knutsford, Cheshire, and was funded by AstraZeneca and Pfizer. AstraZeneca was involved in the study design, collection, analysis and interpretation of data, as well as data checking of information provided in the manuscript. However, ultimate responsibility for opinions, conclusions and data interpretation lies with the authors. This study was originally sponsored by AstraZeneca and is now sponsored by Pfizer. AstraZeneca's rights to the study data were acquired by Pfizer in December 2016.

\section{Author contributions}

EB was the project manager in charge of study delivery. PP was in charge of data interpretation and study report generation. SR-F was in charge of all data analyses from generation of the statistical analysis plan to creation of the final data tables and revision of the study reports. JR-B was the scientific coordinator of the study. Project management within AstraZeneca was provided at different time points by Kamil Jedynski, Yasmina Tazir and Dominic Lim. All authors contributed toward data analysis, drafting and revising the paper, gave final approval of the version to be published and agree to be accountable for all aspects of the work.

\section{Disclosure}

KR and DP are employees of and shareholders in AstraZeneca. SK is a former employee of and shareholder in AstraZeneca. EB and PP are employees of IQVIA (formerly QuintilesIMS), Real-World Insights. SR-F is a former employee of IQVIA (formerly QuintilesIMS), Real-World Insights. JR-B was a scientific consultant for AstraZeneca, Merck, Achaogen and InfectoPharm and has been a speaker in accredited educational activities for Merck. JR-B also receives funding for research 
from Plan Nacional de I+D+i 2013-2016 and Instituto de Salud Carlos III, Subdirección General de Redes y Centros de Investigación Cooperativa, Ministerio de Economía, Industria y Competitividad, Spanish Network for Research in Infectious Diseases (REIPI RD16/0016/RD16/0016/0001), co-financed by European Development Regional Fund "A way to achieve Europe", Operative Program Intelligent Growth 2014-2020. The authors report no other conflicts of interest in this work.

\section{References}

1. Sartelli M. A focus on intra-abdominal infections. World J Emerg Surg. 2010;5:9.

2. Kollef MH, Napolitano LM, Solomkin JS, et al. Health care-associated infection (HAI): a critical appraisal of the emerging threat-proceedings of the HAI Summit. Clin Infect Dis. 2008;47(Suppl 2):S55-S99.

3. Lopez N, Kobayashi L, Coimbra R. A comprehensive review of abdominal infections. World J Emerg Surg. 2011;6:7.

4. Zhang S, Huang W. Epidemiological study of community- and hospital-acquired intraabdominal infections. Chin J Traumatol. 2015;18(2):84-89.

5. Sartelli M, Catena F, Ansaloni L, et al. Complicated intra-abdominal infections in Europe: a comprehensive review of the CIAO study. World J Emerg Surg. 2012;7(1):36.

6. Pieracci FM, Barie PS. Management of severe sepsis of abdominal origin. Scand J Surg. 2007;96(3):184-196.

7. Sartelli M, Weber DG, Ruppé E, et al. Antimicrobials: a global alliance for optimizing their rational use in intra-abdominal infections (AGORA). World J Emerg Surg. 2016;11:33.

8. Kanj SS, Kanafani ZA. Current concepts in antimicrobial therapy against resistant gram-negative organisms: extended-spectrum betalactamase-producing Enterobacteriaceae, carbapenem-resistant Enterobacteriaceae, and multidrug-resistant Pseudomonas aeruginosa. Mayo Clin Proc. 2011;86(3):250-259.

9. Morrissey I, Hackel M, Badal R, Bouchillon S, Hawser S, Biedenbach D. A review of ten years of the study for monitoring antimicrobial resistance trends (SMART) from 2002 to 2011. Pharmaceuticals. 2013;6(11):1335-1346.

10. Munoz-Price LS, Poirel L, Bonomo RA, et al. Clinical epidemiology of the global expansion of Klebsiella pneumoniae carbapenemases. Lancet Infect Dis. 2013;13(9):785-796.

11. Dellit TH, Owens RC, McGowan JE, et al. Infectious Diseases Society of America and the Society for Healthcare Epidemiology of America guidelines for developing an institutional program to enhance antimicrobial stewardship. Clin Infect Dis. 2007;44(2):159-177.

12. Sartelli M, Viale P, Catena F, et al. 2013 WSES guidelines for management of intra-abdominal infections. World J Emerg Surg. 2013;8(1):3.

13. Babinchak T, Badal R, Hoban D, et al. Trends in susceptibility of selected gram-negative bacilli isolated from intra-abdominal infections in North America: SMART 2005-2010. Diagn Microbiol Infect Dis. 2013;76(3):379-381.

14. Eckmann C, Dryden M, Montravers P, Kozlov R, Sganga G. Antimicrobial treatment of "complicated" intra-abdominal infections and the new IDSA guidelines? A commentary and an alternative European approach according to clinical definitions. Eur J Med Res. 2011;16(3):115-126.
15. Hawkey PM. Multidrug-resistant Gram-negative bacteria: a product of globalization. $J$ Hosp Infect. 2015;89(4):241-247.

16. Kollef MH, Sherman G, Ward S, Fraser VJ. Inadequate antimicrobial treatment of infections: a risk factor for hospital mortality among critically ill patients. Chest. 1999;115(2):462-474.

17. Kumar A, Roberts D, Wood KE, et al. Duration of hypotension before initiation of effective antimicrobial therapy is the critical determinant of survival in human septic shock. Crit Care Med. 2006;34(6):1589-1596.

18. Zilberberg MD, Shorr AF, Micek ST, Vazquez-Guillamet C, Kollef $\mathrm{MH}$. Multi-drug resistance, inappropriate initial antibiotic therapy and mortality in Gram-negative severe sepsis and septic shock: a retrospective cohort study. Crit Care. 2014;18(6):596.

19. Raman G, Avendano E, Berger S, Menon V. Appropriate initial antibiotic therapy in hospitalized patients with gram-negative infections: systematic review and meta-analysis. BMC Infect Dis. 2015;15:395.

20. Lucasti C, Hershberger E, Miller B, et al. Multicenter, double-blind, randomized, Phase II trial to assess the safety and efficacy of ceftolozane-tazobactam plus metronidazole compared with meropenem in adult patients with complicated intra-abdominal infections. Antimicrob Agents Chemother. 2014;58(9):5350-5357.

21. Mazuski JE, Gasink LB, Armstrong J, et al. Efficacy and safety of ceftazidime-avibactam plus metronidazole versus meropenem in the treatment of complicated intra-abdominal infection: results from a randomized, controlled, double-blind, Phase 3 program. Clin Infect Dis. 2016;62(11):1380-1389.

22. Sartelli M, Catena F, Ansaloni L, et al. Complicated intra-abdominal infections worldwide: the definitive data of the CIAOW Study. World J Emerg Surg. 2014;9:37.

23. Solomkin J, Hershberger E, Miller B, et al. Ceftolozane/tazobactam plus metronidazole for complicated intra-abdominal infections in an era of multidrug resistance: results from a randomized, double-blind, Phase 3 trial (ASPECT-cIAI). Clin Infect Dis. 2015;60(10):1462-1471.

24. Mazuski JE, Tessier JM, May AK, et al. The Surgical Infection Society revised guidelines on the management of intra-abdominal infection. Surg Infect (Larchmt). 2017;18(1):1-76.

25. Murray BE. The life and times of the Enterococcus. Clin Microbiol Rev. 1990;3(1):46-65.

26. Magiorakos AP, Srinivasan A, Carey RB, et al. Multidrug-resistant, extensively drug-resistant and pandrug-resistant bacteria: an international expert proposal for interim standard definitions for acquired resistance. Clin Microbiol Infect. 2012;18(3):268-281.

27. Sartelli M, Viale P, Koike K, et al. WSES consensus conference: guidelines for first-line management of intra-abdominal infections. World $J$ Emerg Surg. 2011;6:2.

28. Golan Y. Empiric therapy for hospital-acquired, Gram-negative complicated intra-abdominal infection and complicated urinary tract infections: a systematic literature review of current and emerging treatment options. BMC Infect Dis. 2015;15:313

29. Rattan R, Allen CJ, Sawyer RG, et al. Patients with complicated intra-abdominal infection presenting with sepsis do not require longer duration of antimicrobial therapy. $J$ Am Coll Surg. 2016;222(4):440-446.

30. Sawyer RG, Claridge JA, Nathens AB, et al. Trial of short-course antimicrobial therapy for intraabdominal infection. $N$ Engl $J$ Med. 2015;372(21):1996-2005. 


\section{Supplementary materials}

Table SI IECs and IRBs consulted

\begin{tabular}{|c|c|c|}
\hline $\begin{array}{l}\text { Center } \\
\text { number }\end{array}$ & Name and address of IEC/IRB & Date of approval \\
\hline 0101 & $\begin{array}{l}\text { Conselho Municipal de Saúde de Porto Alegre (Porto Alegre Municipal Board of Health) } \\
\text { Ramiro Barcelos, } 2350 \text { - Porto Alegre/RS } \\
\text { 90035-903 Brazil }\end{array}$ & 2 December 2015 \\
\hline 0102 & $\begin{array}{l}\text { Local Ethics Committee for Human Research of the PUC-Campinas (C.E.P.S.H.P.) } \\
\text { Rod. Dom Pedro I, Km I36- Pq. das Universidades - Campinas - SP (São Paulo), Brazil }\end{array}$ & 24 August 2015 \\
\hline 0103 & $\begin{array}{l}\text { Local Ethics Committee of Santa Casa de Misericórdia de Belo Horizonte } \\
\text { Rua Domingos Vieira 590, Santa Efigênia } \\
\text { 30.150-240, MG (Minas Gerais) Belo Horizonte, Brazil }\end{array}$ & 26 October 2015 \\
\hline 0104 & $\begin{array}{l}\text { Pontifícia Universidade Católica do Rio Grande do Sul (“PUCRS") } \\
\text { Research, Innovation \& Development Pro-rector's Office } \\
\text { Partenon } 90.619-900 \text { RS Porto Alegre, } \\
\text { Brazil }\end{array}$ & I5 November 2015 \\
\hline 0201 & $\begin{array}{l}\text { Comitato Etico Università Sapienza } \\
\text { Azienda Policlinico Umberto I } \\
\text { Viale del Policlinico, I55 } \\
00162 \text { Roma, Italy }\end{array}$ & 12 February 2015 \\
\hline 0202 & $\begin{array}{l}\text { Comitato Etico dell IRCCS Itituto Nazionale per le Malattie Infettive Lazzaro Spallanzani di Roma } \\
\text { Via Portuense 292-00149 Rome, Italy }\end{array}$ & 17 February 2015 \\
\hline 0203 & $\begin{array}{l}\text { Al Comitato Etico per la sperimentazione clinica della Provincia di Vicenza c/o Ospedale S. Bortolo viale } \\
\text { Rodolfi } 37 \\
36100 \text { Vicenza, Italy }\end{array}$ & 10 April 2015 \\
\hline 0204 & $\begin{array}{l}\text { Comitato Etico Indipendente dell'Azienda Ospedaliero- Universitaria di Bologna, Policlinico S. Orsola-Malpighi } \\
\text { Padiglione } 3 \text { - Via Albertoni, I5-40I38 Bologna, Italy }\end{array}$ & 4 March 2015 \\
\hline 0205 & $\begin{array}{l}\text { Spedali Civili - Brescia } \\
\text { Comitato Etico Provinciale } \\
\text { Provincia di Brescia } \\
\text { P.le Spedali Civili, I-25I23 Brescia, Italy }\end{array}$ & 14 January 2015 \\
\hline 0206 & $\begin{array}{l}\text { Comitato Etico della Provincia Monza Brianza } \\
\text { Via Pergolesi, } 33-20090 \text { Monza, Italy }\end{array}$ & 2 March 2015 \\
\hline 0301 & $\begin{array}{l}\text { Germans Trias i Pujol Hospital } \\
\text { Research Ethics Committee } \\
\text { Crta. De Canyet, s/n - 08,916 Badalona, Spain }\end{array}$ & 13 January 2015 \\
\hline 0302 & $\begin{array}{l}\text { Clinical Research Ethics Committee of Hospital Universitari Mútua de Terrassa } \\
\text { Plaza Dr Robert, } 5 \text { 0822I Terrassa, Barcelona, Spain }\end{array}$ & I8 December 2014 \\
\hline 0303 & $\begin{array}{l}\text { CREC - Parc de Salut MAR } \\
\text { Dr Aiguader, } 88,08003 \text { Barcelona, Spain }\end{array}$ & 13 January 2015 \\
\hline 0304 & $\begin{array}{l}\text { Clinical Research Ethics Committee of Hospital Clínic de Barcelona Villarroel, } \\
\text { I70-08036 Barcelona, Spain }\end{array}$ & 12 January 2015 \\
\hline 0305 & $\begin{array}{l}\text { Coordinating Biomedical Research Ethics Committee of Andalusia } \\
\text { Hospital Universitario Virgen Macarena } \\
2^{\circ} \text { Planta. Avda. Dr Fedriani, } 3 \\
4107 \text { I Sevilla, Spain }\end{array}$ & 12 December 2014 \\
\hline 0306 & $\begin{array}{l}\text { Research Ethics Committee of the Principality of Asturias C/ Celestino Villamil s/n } \\
33006 \text { Oviedo, Spain }\end{array}$ & 29 January 2015 \\
\hline 0501 & $\begin{array}{l}\text { Moscow City Health Department, The State-Financed Health care Institution Municipal Clinical Hospital No. } \\
\text { I } 2 \text { Ethics Committee, } 26 \text { Bakinskaya St., Moscow II55I6, Russia }\end{array}$ & 6 February 2015 \\
\hline 0502 & $\begin{array}{l}\text { EXPERT Ethics Committee at SPB SBHI (St Petersburg State Budgetary Health care Institution) City Hospital } \\
\text { No. } 40 \\
9 \text { Borisova Street, Sestroretsk, St Petersburg 197706, Russia }\end{array}$ & 19 January 2015 \\
\hline 0503 & $\begin{array}{l}\text { The Local Ethics Committee of the St Petersburg State Budgetary Health Institution, Mariinskaya City Hospital } \\
\text { Liteyny Ave, 56, St Petersburg, Russia }\end{array}$ & 30 December 2014 \\
\hline 0505 & $\begin{array}{l}\text { Ethics Committee, State Budgetary Institution of Health care (SBIH) of Novosibirsk Region (NR) City Clinical } \\
\text { Hospital (CCH) No. } 25 \text { of Novosibirsk } \\
630075, \text { Novosibirsk, Ia Alexander Nevsky Street, Russia }\end{array}$ & 16 February 2015 \\
\hline
\end{tabular}


Table S2 Bacterial pathogens identified in specimen samples, including multidrug-resistant organisms, overall and by country

\begin{tabular}{|c|c|c|c|c|c|c|}
\hline Bacterial pathogen $^{a}$ & $\begin{array}{l}\text { Brazil } \\
(n=67)^{b}\end{array}$ & $\begin{array}{l}\text { France } \\
(n=65)\end{array}$ & $\begin{array}{l}\text { Italy } \\
(n=68)\end{array}$ & $\begin{array}{l}\text { Russia } \\
(n=74)\end{array}$ & $\begin{array}{l}\text { Spain } \\
(n=89)\end{array}$ & $\begin{array}{l}\text { Total } \\
(\mathrm{N}=363)^{\mathrm{b}}\end{array}$ \\
\hline $\mathrm{n}$ & 64 & 48 & 44 & 43 & 71 & 270 \\
\hline 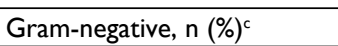 & $50(78 . I)$ & $35(72.9)$ & $34(77.3)$ & $39(90.7)$ & $63(88.7)$ & $22 I(8 I .9)$ \\
\hline Escherichia coli & $31(48.4)$ & $21(43.8)$ & $19(43.2)$ & $17(39.5)$ & $39(54.9)$ & $127(47.0)$ \\
\hline Klebsiella spp. & II (I7.2) & $3(6.3)$ & $6(13.6)$ & $17(39.5)$ & $9(12.7)$ & $46(17.0)$ \\
\hline Pseudomonas aeruginosa & $4(6.3)$ & $5(10.4)$ & $3(6.8)$ & I (2.3) & $17(23.9)$ & $30(1 \mathrm{I} . \mathrm{I})$ \\
\hline Enterobacter spp. & $7(10.9)$ & $3(6.3)$ & $8(18.2)$ & $0(0.0)$ & $5(7.0)$ & $23(8.5)$ \\
\hline Acinetobacter spp. & $4(6.3)$ & $0(0.0)$ & $\mathrm{I}(2.3)$ & $6(14.0)$ & $3(4.2)$ & $14(5.2)$ \\
\hline Proteus spp. & $\mathrm{I}(\mathrm{I} .6)$ & $\mathrm{I}(2 . \mathrm{I})$ & $0(0.0)$ & $\mathrm{I}(2.3)$ & $4(5.6)$ & $7(2.6)$ \\
\hline Citrobacter spp. & $0(0.0)$ & I (2.I) & I (2.3) & $0(0.0)$ & $2(2.8)$ & $4(1.5)$ \\
\hline Serratia spp. & $0(0.0)$ & $I(2 . I)$ & $0(0.0)$ & $2(4.7)$ & $\mathrm{I}(\mathrm{I} .4)$ & $4(1.5)$ \\
\hline Morganella morganii & $\mathrm{I}(1.6)$ & $\mathrm{I}(2 . \mathrm{I})$ & $0(0.0)$ & $0(0.0)$ & $0(0.0)$ & $2(0.7)$ \\
\hline Haemophilus spp. & $0(0.0)$ & $I(2 . I)$ & $0(0.0)$ & $0(0.0)$ & $0(0.0)$ & $\mathrm{I}(0.4)$ \\
\hline Salmonella spp. & $0(0.0)$ & $0(0.0)$ & $0(0.0)$ & $0(0.0)$ & $\mathrm{I}(\mathrm{I} .4)$ & $\mathrm{I}(0.4)$ \\
\hline Other & $\mathrm{I}(\mathrm{I} .6)$ & $2(4.2)$ & $2(4.5)$ & $0(0.0)$ & $7(9.9)$ & $12(4.4)$ \\
\hline Gram-positive, $n(\%)^{c}$ & $20(3 \mid .3)$ & $19(39.6)$ & $18(40.9)$ & $6(14.0)$ & $29(40.8)$ & $92(34.1)$ \\
\hline Enterococcus spp. & $8(12.5)$ & $15(31.3)$ & $8(18.2)$ & $5(11.6)$ & $18(25.4)$ & $54(20.0)$ \\
\hline Staphylococcus spp. & II (I7.2) & $4(8.3)$ & $7(I 5.9)$ & $0(0.0)$ & $7(9.9)$ & $29(10.7)$ \\
\hline Streptococcus spp. & $2(3.1)$ & $2(4.2)$ & $4(9.1)$ & $\mathrm{I}(2.3)$ & $7(9.9)$ & $16(5.9)$ \\
\hline Other & $0(0.0)$ & $\mathrm{I}(2 . \mathrm{I})$ & $0(0.0)$ & $0(0.0)$ & $\mathrm{I}(\mathrm{I} .4)$ & $2(0.7)$ \\
\hline 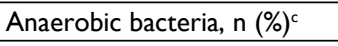 & $0(0.0)$ & $9(18.8)$ & $2(4.5)$ & $0(0.0)$ & $10(14.1)$ & $21(7.8)$ \\
\hline Bacteroides spp. & $0(0.0)$ & $6(12.5)$ & $2(4.5)$ & $0(0.0)$ & $7(9.9)$ & $15(5.6)$ \\
\hline Clostridium spp. & $0(0.0)$ & $2(4.2)$ & $0(0.0)$ & $0(0.0)$ & $2(2.8)$ & $4(I .5)$ \\
\hline Prevotella spp. & $0(0.0)$ & $I(2 . I)$ & $0(0.0)$ & $0(0.0)$ & $0(0.0)$ & $\mathrm{I}(0.4)$ \\
\hline Other & $0(0.0)$ & $0(0.0)$ & $0(0.0)$ & $0(0.0)$ & $\mathrm{I}(\mathrm{I} .4)$ & $\mathrm{I}(0.4)$ \\
\hline Other bacterial agent, $\mathrm{n}(\%)^{\mathrm{c}}$ & $I(1.6)$ & $2(4.2)$ & $0(0.0)$ & $0(0.0)$ & $3(4.2)$ & $6(2.2)$ \\
\hline \multicolumn{7}{|c|}{ Multidrug-resistant pathogen, $\mathrm{n}(\%)^{\mathrm{c}}$} \\
\hline Yes & $20(31.3)$ & $23(47.9)$ & $14(31.8)$ & $22(5 \mid .2)$ & $33(46.5)$ & $\mathrm{II} 2(4 \mathrm{I} .5)$ \\
\hline No & $44(68.8)$ & $25(52.1)$ & $30(68.2)$ & $21(48.8)$ & $38(53.5)$ & $158(58.5)$ \\
\hline Missing & 25 & 17 & 24 & 31 & 18 & 115 \\
\hline Fungal pathogen, $\mathrm{n}(\%)^{\mathrm{d}}$ & $2(3.0)$ & $8(12.3)$ & $5(7.4)$ & $0(0.0)$ & $15(16.9)$ & $30(8.3)$ \\
\hline
\end{tabular}

Notes: aPatients could have more than one pathogen type identified. ${ }^{\mathrm{b}} \mathrm{Data}$ missing for 22 patients in Brazil. cPercentages are calculated as a proportion of those patients with $\geq$ I bacterial pathogen identified. dPercentages are calculated as a proportion of the overall population.

\section{Publish your work in this journal}

Infection and Drug Resistance is an international, peer-reviewed openaccess journal that focuses on the optimal treatment of infection (bacterial, fungal and viral) and the development and institution of preventive strategies to minimize the development and spread of resistance. The journal is specifically concerned with the epidemiology of antibiotic
Dovepress

resistance and the mechanisms of resistance development and diffusion in both hospitals and the community. The manuscript management system is completely online and includes a very quick and fair peerreview system, which is all easy to use. Visit http://www.dovepress.com/ testimonials.php to read real quotes from published authors.

Submit your manuscript here: https://www.dovepress.com/infection-and-drug-resistance-journal 